This is the pre-print of our paper accepted by EPG and is to be cited as: Rodela, R., Udovč, A., Boström, M., 2017. Developing Environmental NGO Power for Domestic Battles in a Multilevel Context: Lessons from a Slovenian case. Environmental Policy and Governance.

\title{
Developing Environmental NGO power for domestic battles in a multi-level context: lessons from a Slovenian case
}

\section{Introduction}

The safeguard of 'public interests' on matters of environmental protection is both a domestic and a transnational concern. Likewise, it is both a question of legal frameworks giving access to certain rights and a question of governance structures that, among other, include participation of interest groups such as environmental non-governmental organizations (ENGOs) operating for the public good (Slepcevic, 2009). In this article, ENGOs are understood as organizations not affiliated with state authorities, who have a clear environmental focus, operate as not-for-profit and have a base of voluntary members or participants. ENGOs employ a broad repertoire of activities: from educational and awareness raising campaigns directed to citizens, to mobilization of high profile expertise meant to influence policy processes. This article focuses on the latter category.

Many scholars have discussed the crucial role ENGOs had for the implementation of nature protection policy across the European Member States (e.g. Fairbrass and Jordan 2001, Weber and Christophersen, 2002; Cent et al., 2013; Mertens, 2013). ENGOs have given key input to the identification of areas of community importance (i.e., Special Protection Areas, Special Areas of Conservation) and later contributed to monitor the implementation of requirements arising from the Habitat Directive that turns these into protected areas. These studies reveal the new opportunities that distributed decision-making in an enlarged European Union offers. ENGOs have been able to by-pass national governments and exert pressure on these from the outside. This is also referred as a boomerang strategy (Keck and Sikkink 1998; Hochstetler, 2002). However, opportunities are not evenly spread around the EU member countries. Börzel and Buzogány (2010) warn against broad generalisations on the opportunities the EU brings and ways in which ENGOs react on these. Crucial differences among new and old Member States imply that not all ENGOs can act and undertake activities in the same way and with the same intensity. In this article, we address their warning; we seek to contribute on the role of ENGO capacity building within a context of multilevel environmental governance.

In this study we look closer at the details of an empirical case located in a Central European country, Slovenia, with the aim to gather insights into how ENGOs, given economic and political constraints present in the region, develop capacities, gather and use resources to move vertically and horizontally in efforts to win a domestic battle. The study focuses on the details of a case where Slovene ENGOs mobilised against the siting of a wind-park on the Volovja reber of which one part was suggested for protection under the Habitat Directive. The dispute involved ENGOs seeking to pursue nature protection objectives from the EU Birds and Habitats Directive against state authorities who on the other hand prioritized green energy and supported investors' plans for siting 80 windmills on that location. 


\section{Multi-level Environmental Governance and the role of ENGOs in Nature Protection}

Environmental governance is a term that in its broadest conception refers to social and political processes meant to coordinate human activities in relation to the natural environment. Such coordination includes collective will-formation, decision-making, formation of formal and informal institutions, and deliberation among different actors. There is no widely agreed definition of environmental governance. While some suggest linking the concept to the development of the European integration processes and the opportunities this offered for environmental protection (Fairbrass and Jordan, 2004; Hooghe and Marks, 1996; Marks and Hooghe, 2004) others see it as part of critiquing top-down resource management (Rauschmayer et al., 2009). However, what these different viewpoints share is an interest for various implications of both horizontally and vertically distributed decision-making (cf. Boström and Karlsson, 2013). The notion of multi-level governance, often used in studies of European governance and policy implementation, adds a spatial dimension to distributed decision-making and deliberation. Studies have emphasized the interplay between national governments, European institutions, and non-governmental actors (e.g., Baker, 2003; Börzel and Buzogány, 2010; Carmin and Vandeveer, 2004; Evans et al., 2013; Grodzinska-Jurczak and Cent, 2001; Kluvánková-Oravská et al., 2011; Weber and Christophersen, 2002).

This study focuses particularly on the role of ENGOs in such multi-level governance contexts. Scholars address how environmental activism pursue local environmental agendas through bypassing state authorities and directing queries at supranational bodies. For example, in a seminal paper Fairbrass and Jordan (2001) show that contemporary biodiversity policy in Britain cannot be explained with state-centric theories alone, since much of it is the result of a certain type of environmental activism interfacing with both national and supranational bodies (e.g., the European Court of Justice). Weber and Christophersen (2002) report on how ENGOs across Member States joined forces to push national authorities in the accomplishment of nature protection obligations arising from the Birds and Habitats Directives. Their analysis highlights that within this policy domain ENGOs were granted an important role by the European Commission (EC). At the end of the 1980s an international and independent initiative coordinated by BirdLife International that involved local ENGOs led to what are today known as Important Bird Areas (IBA), a list of important habitats for the conservation of bird populations. Later, the EC used this list to cross-check the appropriateness of site suggestions submitted by Member States (Weber and Christophersen, 2002). In several cases, after cross-checking with the IBA, the EC asked national governments for adjustments of their submitted lists. Also, at a later stage ENGOs acted as watchdogs (i.e., watching over the national government actions) alerting the legal department of the DG Environment when Member States failed to fulfil obligations and for instance have designated for protection a much smaller area than the one suggested in the IBA (Krott et al., 2000; Weber and Christophersen, 2002). Accordingly, the possibility to feed in comments and informed opinion about environmental issues at the EU level offered an opportunity for ENGOs to influence domestic protection objectives and allowed them to monitor compliance with EU policy.

However, nature protection policy might be understood as a special case as there is a need for policy-makers to draw upon large amounts of fresh international scientific data, something which national-level state bodies with duties in nature conservation might not always be in a position to deliver as fast and flexibly as ENGOs can. ENGOs can employ own expertise, foster useful link with scientific networks and they can, in addition, rely on volunteers to participate in data collection for 
biodiversity monitoring (Bell et al., 2008). This trend has benefited ENGOs by increased legitimacy in the eye of European policy-makers.

But the opportunity and capacity for ENGO to play an influential role in the multi-level governance context must be seen as context dependent (Börzel and Buzogány, 2010). ENGOs based in different Member States cannot engage in the same way across all policy areas, because of, firstly, varying domestic political opportunities, and secondly, varying domestic opportunities for resource mobilization. We will, in what follows, refer to social movement theory to elaborate on these two concepts.

The concept of political opportunity structures refers to a cluster of variables, including access to party politics, policy-making processes, state administration, and legal institutions (e.g., McAdam, 1996). This concept has been utilised to examine how social movements are shaped by the political opportunities and constraints of a given political context, i.e., within a nation-state. Studies demonstrate that social movements will strategically develop activities, priorities, and tactics in relation to perceived opportunities and threats. However, like it is stressed by the multilevel governance theory, recent research has convincingly demonstrated the importance to take into account how domestic and international political opportunity structures are nested and interact in dynamic interplay (e.g., Meyer, 2001; Josselin, 2007; Boström et al., 2015). Another core theme in social movement research is resource mobilization (McAdam et al. 2005). Explanations that focus on resource mobilization emphasize that organizations emerge and grow thanks to ability to accumulate, control, use and organize various resources. These are not just material resources such as financial resources, equipment, voluntary or paid working time have, but also cognitive (expertise and experience), symbolic (recognition) and social (personal contacts, networks) (see: Boström and Tamm Hallström, 2010). These four types of resources can be combined to a fifth category, monitoring power; that is, 'ability to assess performance against promises and to expose the distance between rhetoric and practice' (ibid. p. 48). The ENGOs role to act as watch-dog in the case of biodiversity governance as described above, is a good illustration. Monitoring power requires time and resources to follow how a case develops (that can be domestically but also transnationally). Of interest to our analysis is how local ENGOs can mobilize and organize resources on both horizontal and vertical axes, and develop capacity for domestic action.

Ability to exercise power and mobilize resources in a transnational context requires a degree of organization and institution-building (Boström and Tamm Hallström, 2010). In the literature on environmental movements, a core theme has been the development of movements from informal, radical, and grassroots features into formal organizations with agendas that goes beyond awareness-raising campaigns towards influencing policy at the highest administrative level (Diani and Rambaldo, 2007; Hann and Dunn, 1996; Rootes, 2003). Although there are substantial differences across EU states (Rootes, 2003), ENGOs are today generally performing as wellorganized interest groups who contribute to shape policy agendas on a number of environmental topics (e.g., nature protection, pollution, climate change) at national, European, and global levels. However, when it comes to the post-communist context we need to acknowledge the impact that closed domestic political opportunities structures have on ENGOs. Specifically, low-trust and a non-transparent political culture do not help ENGOs in capacity building. There is a growing number of studies that focus on Central and Eastern Europe (CEE), and differences in resource opportunities between North West and CEE countries has been discussed in terms of participatory versus transactional activism (Petrova and Tarrow, 2007). This implies that many ENGOs from 
post-communist countries have become fundamentally reliant on project-based money (international and national grants) or institutional donors. Mobilization of mass membership, which is common in the North West, is a less feasible option in that context due to lack of history of mass mobilization and low trust towards institutions, including civil society (Jacobsson and Saxonberg, 2013).

A noted problem, in such cases, is that international concerns may take precedence before local concerns in domestic mobilization (Bell, 2004; Hicks, 2004; Waller, 2010). Yet, we also need to ask if international concerns can be creatively utilized to raise the profile of local concerns, and increase the capacity of local ENGOs for domestic pressure. Indeed, other studies indicate a considerable amount of flexibility and room for local creative movement action in the postcommunist context despite rather closed domestic political opportunity structures (Císař, 2010; Jacobsson and Saxonberg, 2013). Lack of organizational resources on the domestic level (financial, large membership) could be compensated by other type resources (e.g. social capital) (Boström et al., 2015). For example, Sudbery (2010) found that while EU implied some type on constraints on NGO, these could actively use the political resources that EU brings in domestic campaigning. The EU provides a repertoire of legal tools, policy instruments, norms and discourses that can be used in domestic agenda setting and monitoring of domestic policy.

\section{Methods}

The study focuses on the details of an empirical case where Slovene ENGOs mobilised against the siting of a wind-park on the Volovja reber, a natural site listed in the International Birds Areas, falling under obligations arising from the Birds and Habitats Directive (i.e. Natura 2000 sites). This case offers an opportunity to further investigate how in the face of given constraints ENGOs mobilise horizontally but also vertically to pursue nature protection.

This study is based on a bibliographic search into a national database (COBISS) with search terms "Volovja reber", used in combination with "nature protection", "Natura 2000", "energy policy" and "wind-power plant" (all in Slovene language). This resulted in articles published in the national, regional and local press, followed by diploma and master theses and reports. A search of international bibliographic databases (Web of Science; Scopus) was undertaken but yielded no useful outcomes. Additionally, several Internet searches were undertaken (using Google as a search engine) with the same key words used in Slovene and English at different periods (in 2012, in 2013 and the last in 2014). This resulted into reports, official letters and protocol documents issued by Slovenian and European institutions. The final sample of data-sources comprised 44 media articles, 20 reports, four peer-reviewed publications and 15 official letters.

We should mention that attempts were made to obtain interview data. In 2008 and in 2009 stakeholders involved in this dispute were contacted with the aim of conducting a semi-structured interview. Despite having clarified our objectives (i.e. research and pedagogical) and affiliations (i.e. university), our requests were turned down as the sensitive case was still running, with the exception of an ENGO who agreed to meet. The information gathered during that interview helped to understand how this ENGO works. However, when asked about this case the respondent politely replied "cannot comment as the case is still in court". For this reason we choose to base our analysis on bibliographic material.

This study is focused on ENGO operating within a specific country context and so there are implications for the type of generalizations that can be drawn from this analysis. While the results 
obtained may allow us to draw implications at the level of theory and conceptual tools used (Yin, 2008), some of our findings have broader relevance for future studies of ENGOs mobilization and specifically for those focusing on ENGOs in Central and Eastern European counties.

\section{Results and Discussion}

\section{Opportunity structures}

Slovenia became a sovereign state in 1991. Prior to this it was part of the Yugoslav Federation, and earlier of the Yugoslav Monarchy, and during all of these historical periods power centres were located outside Slovenia (e.g., Vienna, Belgrade) which had implications for state-society relationships as well as nature protection. For instance early endeavours in nature protection were pursued by a group of natural scientists who studied in Vienna and were influenced by certain ideas about strict separation of man from nature and thus favouring strict forms of nature protection. The idea about pristine nature and the (non-) role of humans within it had a profound influence on later conceptualisations of nature protection practice in Slovenia. It was carried forward into the first institutions with duties in this domain formed during the period of the Yugoslav Federation (Banovec et al., 2006). During this period (1945-1991), nature protection moved from the domain of voluntary engagement and private commitment, driven by the idealistic visions of a few (educated locals/scientists), into the domain of the state. At the end of the 1980s Slovenia already had an independent system for the protection of the environment, consisting of a specialised bureau, several decrees for the protection of species of flora and fauna and one protected area. A further aspect of interest is that the Yugoslav federation introduced a two-tier division of competences between the government and the municipalities with competences in local affairs, e.g. infrastructure. This division, in several cases, allowed for local opposition to form and win over development projects viewed as harmful to the environment - a dam in the upper Soča valley, a plant on Lake Bohinj and a cableway on Mt. Triglav encountered strong resistance and were turned down (Berginc et al., 2007; Tickle and Clarke, 2000). The latter suggests that although activism was not very 'loud' during the Yugoslav period, it did not disappear; it had a low profile and was active on issues of local relevance. Accordingly, it is important to acknowledge the small although firmly rooted local interest for nature protection in Slovenia that established a basic platform for later political struggles.

However, it was only after 1991, after Slovenian independence, that more substantial reforms took place and that the nature protection institutional framework was modernised. Duties in this area moved from the Ministry of Culture to the newly formed Ministry for Environmental Protection and Spatial Planning. At the end of the 1990s, a revised legal framework was formulated. It provided a comprehensive definition of nature protection and better opportunities for the accomplishment of obligations arising from the signing of international conventions, e.g. the Convention on Biodiversity, the Alps Convention, the Ramsar Convention and the Kyoto Protocol and others (Berginc et al., 2007). In the period after independence, only a few NGOs were formally registered and had a semi-professional structure (Podjed and Muršič, 2008). However, this changed with the prospect of the enlargement and access to EU funds as many applied for a legal status needed to access the funds. Still, most Slovene ENGOs are operating as associations with a small membership base ranging from 30 to 100 members and are focusing mostly on issues of local relevance. There are only a few ENGOs that have a professional, or a semi-professional structure, that employ staff members, run thematic projects, have the capacity to interface with policy-makers and run nationwide awareness campaigns (Bell et al., 2011). Detailed analyses that 
disclose how, on what issues and how frequently ENGOs interface with policy and decision makers are not available. However, observers critiqued that when that happens ENGO involvement occurs at the last stages of decision-making processes and outcomes of it are unclear (Škrl-Marega, 2007; Verbajs, 2006).

In 2010, of 225 environmental organisations registered, only 36\% focused exclusively on environmental topics, with the majority of the ENGOs also engaged in cultural, recreational and other activities and many not being active. Most of the Slovene ENGOs are small and are engaged on activities perceived to have only local relevance (Oblak, 2004). The topics and geographic range of ENGO activities are very important to gain access to environmental justice and to be involved in formal procedures. According to changes in the Slovene institutional framework resulting from the transposition of the Environmental Impact Assessment Directive, ENGOs that are formally registered and actively engaged on the whole national territory on pressing environmental issues for more than five years can apply for legal standing as NGOs acting in the public interest. That is, these ENGOs can acquire the right of appeal and ask for inclusion in, e.g. environmental impact assessment (EIA) procedures and processes around environmental and construction permits. The right of appeal allows the ENGOs to access judicial review, bring a case in front of the Administrative Court and challenge decisions issued by specific institutions, e.g. those relating to environmental permits and construction permits. The right of appeal can be granted under two separate acts, the Environmental Protection Act (EPA) and the Nature Conservation Act (NCA). Depending on the ENGOs main area of engagement the right of appeal can be granted either under the NCA, if prevalently active on nature protection, or under the EPA if prevalently active on environmental protection. This is why it matters on what topics and projects, and for how long the ENGOs are active. According to data from 2011, 25 ENGOs were granted the right of appeal under the EPA and 14 under the NCA. Five of these ENGOs were granted the right of appeal for both nature and environmental protection.

\section{The Volovja reber case}

Volovja reber is limestone ridge part to a larger karstic landscape. It is remote and inhabited. After the abandonment of traditional agricultural practices a part of this land saw natural reforestation. An analysis of wind potential across five regions (Italy, Spain, Slovakia and Slovenia) funded under the EU Programme ECOS-OUVERTURE ${ }^{1}$ (WEP I - Wind Energy Potential project) found that Volovja reber, along with three other locations, had good potential as a site for a wind park. Electro Primorska, a Slovenian energy distribution company (79.5\% state owned), and Gamesa Eolica, a Spanish wind turbine producer, set up a partnership with the objective of locating a $28.05 \mathrm{MW}$ wind park with 88 turbines. This was aligned with the Slovene National Energy Plan, which integrates obligations from EU directives as is the directive on the promotion of electricity from renewable sources (2001/77/EC) and the directive on common rules in electricity and repealing for the internal market (2003/54/EC), among others. The prospective of this investment received full support from local and national political decision makers. At that time, a survey commissioned by the investors stated that the majority of local inhabitants were in favour of sitng 88 turbines, and both the inhabitants and municipal authorities saw the development as a substantial economic opportunity that could facilitate employment and reduce energy costs (Kos et al., 2003). In February 2003, the municipal council approved changes to the spatial plan that included a wind park on Volovja reber (Official Gazette RS no. 19/2003). After an initial rejection in 2004, because

\footnotetext{
${ }^{1}$ ECOS-OUVERTURE Programme: Inter regional co-operation between local authorities in the European Union and Central and Eastern Europe (1997-2003). Information accessible in the archives here http://ec.europa.eu/regional_policy/archive/innovation/innovating/ecos.htm
} 
of an incomplete impact assessment, the Environmental Agency issued a permit in 2006 to site 33 of the 88 planned wind turbines.

The reaction from ENGOs to the prospect of an infrastructural development they regarded harmful to local flora and fauna was immediate. In May 2003, the Slovene bird watch association Društvo za opazovanje in proučevanje ptic (DOPPS), who is a member to BirdLife international, issued a statement listing locations and reasons why these sites were not suitable for wind turbines. Together with 23 other Slovene ENGOs, DOPPS formed a coalition², which began to pursue a mobilisation campaign. The coalition brought together Slovene associations, foundations, and civil society groups active on the topic of nature protection. With DOPPS taking the lead the coalition has been since then consistantly engaged in lobbying and monitoring the case (further analysed later the next section). The steps this coalition took had major implications on how this case developed and contributed to raise the attention of European policy-makers towards infringements of EU recommendations and policy objectives.

Earlier, in the mid-1990s, there was an attempt to designate the wider natural area around Volovja reber (referred to as Snežnik Park) for protection. Local ENGOs, municipalities, donors (i.e. Dutch funds), the Ministry and the Environmental Agency have been involved in that initiative. However, the protected area establishment came to a halt in 2000 and was never completed. Yet, the preparatory work done in that occasion served at a later stage when Slovenia, in the view of EU accession, had to designate areas of community importance as part of the Natura 2000 ecological network (Ogorelec and Mastnak, 1999). In response to obligations arising from the Birds and Habitats Directives the Snežnik and Pivka territory was designated for protection under the Snežnik-Pivka SPA SI5000002 - of which part includes Volovja reber. However, according to an investigation undertaken by the Slovene Commission for the Prevention of Corruption, in 2006, based on a last-minute decision by the then minister, Volovja reber was removed from the Natura 2000 site - so the size of the proposed Natura 2000 site was down-scaled from 54,906 ha to 48,522 ha (see: Kos, 2007). In 2007, an official inquiry conducted by the Slovene Commission for the Prevention of Corruption concluded that the exclusion occurred because of plans for infrastructural development (see: Kos, 2007) since Volovja reber has attracted the interest of investors in renewable energy.

In a report on this case, prepared by the then Ministry of the Environment and Spatial Planning for the Standing Committee of the Convention on the Conservation of European Wildlife and Natural Habitats, it is noted that the local community opposed to the designation of that area as a Natura 2000 site. The Ministry estimated that the area is valuable but not crucially significant for the favourable conservation status of species and habitat types and thus it was not included in the list of proposed Natura 2000 sites.

In 2007 the EC issued a warning against infringements (no. 2007/2185) of the Directive 79/409/EEC, for nine Natura 2000 sites, which were set to a much smaller size than suggested in the IBA. The letter listed Volovja reber as well. Also it noted that the identification of Natura 2000 areas must be based on ornithological criteria only and all other, inclusive of economic and social criteria should not have an influence on the identification process. The EC explicitly pointed at insufficiencies in relation to 23 species (listed in the IBA). In a reply to the EC on 23 August 2007 the Slovene government listed circumstances (species distribution) which justify a degree of discretionality for 9 species, while for the other 14 (bird) species the government said it will work towards compliance within planned revisions of the Regulation on special protection areas (Natura 2000). Also, it stated that with regard to the

\footnotetext{
${ }^{2}$ Official site of the coalition with information about full set of activities accessible here: http://www.volovjareber.si
} 
Snežnik-Pivka special protection area, due to population fluctuation and lack of recent scientific data, further assessments were needed. The government asked for further 6 months to study this specific case. In agreement with the EC the case was under exploration until 2011. In November 2012 the EC sent a reasoned opinion which is the second stage of the infringement procedure and wrote in that communication that in case of unsatisfactory response, the Commission may refer Slovenia to the EU Court of Justice. In April 2013 the government issued amendments which increased the Natura 2000 sites to 59600 ha and has provided a reply/justification to the EC for the changes made (Reply to EC from the 15 April 2013 - no. 5423-74/2010). Thus it has assigned 5 new areas, increased the territory of 20 areas and declassified one area. The Snežnik-Pivka ${ }^{3}$ (SPA SI5000002) resulted with 54810.50 ha

The revised list of Natura 2000 sites $(\mathrm{N}=31)$ submitted does not match $100 \%$ with the IBA inventory. In the media release accompanying the amendments it is noted that "differences between the requests made by the EC and amended Natura 2000 sites was motivated by technical arguments. Therefore, we expect that the process against Slovenia will be stopped and the Commission will not pursue litigation" (extracted and translated in English from http://www.natura2000.gov.si). The EC has explored the submitted amendments and approved the corrections submitted by the authorities.

\section{ENGOs Resources and Mobilisation Strategies}

In this section we will give further details of the dispute surrounding the Volovja reber and in parallel analyse how ENGOs identified, mobilised, used, and combined different resources in a multi-level context.

Cognitive resources: It is with reference to how the ENGO coalition, and DOPPS as the lead, handed the steps that followed that informs on the role of cognitive resources of the ENGO coalition has - i.e. scientific knowledge (biodiversity) and sectorial expertise (legal procedures national and internationally). Within the coalition it was the only ENGO to have specific expertise, staff and knowledge of the bureaucratic procedures. It is useful to mention that when DOPPS first submitted in September 2004 the request for getting the formal status of an "ENGO representing public interests" the Environmental Agency refused the request, claiming that the NCA was insufficient to grant access to this specific case. Later DOPPS applied for the right of appeal under EPA which was granted to DOPPS by the Ministry, after which it made a further request to be included in the EIA. The request was rejected for a second and later for a third time. In 2006 DOPPS turned to the Administrative Court, which ruled in favour of this ENGO, after which the investors filed a complaint against this decision to the Supreme Court, which confirmed the previous decision (Jančar, 2007).

In 2007 DOPPS succeed in getting the status of accessory participant and it provided scientific evidence about the presence of rare and endangered species, specifically, the golden eagle Aquila chrysaeto, claiming proof that turbines would cause severe harm (i.e. scientific knowledge). This challenged the previous assessment and a second round of EIA was undertaken in 2008, when DOPPS represented public interests in matters of environmental protection. On the basis of an external and independent appraisal performed by British scientists, DOPPS again provided scientific evidence supporting the claims that the wind park represents a harm. However, in 2011 the Agency again confirmed the permit for 33 turbines, against which DOPPS filed a further complaint at the Administrative Court, which again ruled in favour of nullifying the new permit. A fourth round of assessments resulted in the Agency recalling the environmental permit for the 33 wind turbines, and associated infrastructure, issued back in 2006 (letter available at the http://www.volovjareber.si ${ }^{4}$ )

\footnotetext{
${ }^{3}$ http://www.natura2000.si/index.php?id=105\&area_id $=262$

${ }^{4}$ http://www.volovjareber.si/gradivo/novice/20130506-ARSO--

OkoljevarstvenosoglasjezaVEVolovjarebersezavrne20130507_Redacted.pdf
} 
Material resources: as in many other CEE countries access to funds is a major challenge Slovene ENGOs face today. In contrast with ENGOs from North-West European countries, Slovene ENGOs cannot rely on members' fees for subsistence as the membership base is small. For this reason they need to target national (e.g. municipality, Ministry) and international calls. While these provide opportunities to apply for financial resources, competition among ENGOs is fierce with few gaining access to these. From a list of grants allocated to ENGOs from 2008-2010 (list supplied to author, personal communication) it is noticeable that Slovenian Ministers co-fund only "soft" activities such as awareness-raising and educational activities. Projects centred on activities such as capacity building and strengthening of participatory democracy must be funded from international sources (e.g., the Mantra project for Snežnik Park protection; Interreg SI-HU for Goričko Park protection). Yet, due to the economic crisis that has hit upon some European member states, grants to ENGOs have decreased significantly.

ENGOs participating in the above mentioned ad-hoc formed coalition thus face challenges in accessing financial resources. DOPPS appears as the most successful in this regard. In 2003 it was one among few Slovene ENGO to have a well-working partnership with a major business company (Telekom Slovenia), and was able to recruit permanent and well trained staff members, has mobilized the largest voluntary base in the country - according to Podjed and Muršič (2008) is has approximately 750 members) and through member of BirdLife International has access to international experts. From all the coalition members DOPPS profiled as the one with the resources needed to assume a leadership role and embark on a specific mobilisation strategy even if resources were scarce.

Previous research has shown that actors with limited resources and opportunities to pursue their interests within a given policy arena often turn to international and domestic courts, as these constitute an independent body with power over governmental institutions (Börzel and Buzogány, 2010; Golub, 1996; Hilson, 2002). The Volovje reber case is illustrative of this strategy. Given the shortage of finance to undertake major and deep-cutting national awareness raising campaigns and given the uncertain outcomes that campaigns can have in case of controversial investments, the ENGOs coalition has chosen for litigation as a mobilisation strategy. On the other hand, money is needed also for litigation- in this case each time they turned to courts were on average around 400 Euros, added to these are the costs for legal representation, costs need for the studies and reports produced. These are not negligible expenses, given the difficulties Slovenian ENGOs have in accessing funds, and only DOPPS had a realistic resource opportunity to go for this strategy.

This case is characterised by a litigation strategy and this was possible mainly due to changes of the legal framework that Slovenia, the view of EU accession, has to harmonise up to the EU requirements. Well aware of the rights that the EU Directives brought in 2004 DOPPS requested to be included in the Environmental Impact Assessment procedures as an ENGO representing public interests on the basis of the right of appeal it had been given under the NCA (Jančar, 2007). As the lead of the coalition DOPPS has coherently moved along a strategy that seeks the enforcement of officially recognised rights (i.e. access to environmental justice).

Social resources: the role of partnerships and collaborative activities at multiple levels is perhaps the most important type of resource in this case given that it allowed to compensate for lack of scarce financial resources and to capitalize on local knowledge and expertise. At a national horizontal level the coalition acted as a compact entity that challenged established powers from 
within by means of a litigation strategy. But the coalition also moved vertically - with DOPPS as a step stone to BirdLife International gaining access to external expertise, contacts and network. Bell at al. (2010) notice that DOPPS has successfully gather together an informal "working group" within BirdLife who offered expertise and guidance and these not only offered input on questions of scientific nature but also advice on strategies to take in similar cases. As a member of BirdLife International DOPPS had a role earlier during the 1970s-80s when BirdLife was compiling information then used to put together the IBA, and later provided information about Slovenian compliance with the Habitat Directive (see: Weber and Christophersen 2002). This data was used by the EC who on 27 June 2007 issued a warning to the Ministry of the Environment against infringements (no. 2007/2185) for nine Natura 2000 sites, which the Ministry set to a much smaller size than suggested in the IBA. In the letter the EC sent to the Ministry Volovja reber it was listed. It is known that failure to complain with EU requirements of this type may lead to monetary sanctions, bad reputation and further complications we assume this put some degree of pressure on the authorities.

Thus, we note that a combination of horizontal and vertical engagement and collaborations, which were possible mostly thanks to DOPPS membership in BirdLife International, proved important and allowed that issues around compliance with the European legislation could emerge strongly pressing from the outside (i.e. warning by European institutions) on national decision-making.

Symbolic: the linkage to international circumstances (EU/BirdLife) could potentially provide legitimacy for a local battle, showing how a local issue is globally connected, recognized and endorsed. However, in this case, it was more important to gather domestic profile actors to gain increasing legitimacy. DOPPS itself is more recognized than its international affiliation BirdLife. Important to note also is, as described earlier, the rooted local interest for nature protection in Slovenia that grow during the Yugoslav historical period.

While this case is characterised by legal mobilisation, we also recognised a strategic use of domestic symbolic resources when preparing and running activities round this case. The coalition was, nevertheless, speaking to Slovene people about a matter of local relevance. For instance two petitions were organised. One in 2004 in collaboration with associations and an well-established Slovene foundation, Umanoterra, (2400 signatures) and one in 2007 in collaboration with a national wellestablished critical magazine, Mladina (5180 E-signatures). Teaming up with these supporters is not coincidental as both have a history of being dissident voices speaking and pointing to issues with mainstream political choices. Umanoterra was the first Slovene foundation that focuses on issues around environmental protection and is regularly warning against policy inconsistencies, while Mladina an un-orthodox and satirical newspaper $(20,000$ copies per week) is one of the most influential political magazines in the country. As supporters to the initiative and promoters of the petitions both have contributed with their renome' to raise the profile of the arguments made. In both cases nature protection was emphasised as an important cornerstone of Slovene environmental governance that cannot be overridden by policy objectives on renewable energy. Also, two protest marches (both in 2007) and several round tables and public debates were organised. Media coverage was significant and developed around views in favour of nature protection.

As already pointed out by Slepcevic (2009) litigation against non-compliance with domestic or European law requires resources that can be mobilized and utilized in a multilevel governance context. It costs money, it requires both international and domestic support, and requires that ENGOs members, volunteers and activists understand well the legal and institutional framework within which they are operating. It is not coincidental that among the 24 coalition members it was DOPPS who took the lead since it was the only actor that had access to international networks and 
expertise. This coalition with one core ENGO were a game changer with deep implications not only on the type of mobilisation strategy pursued but also on the type of power exercised. DOPPS alone could not push forward the issue, but it could function as the central node by orchestrating a set of power resources that were dispersed both horizontally on the domestic level and vertically on the international level.

A further aspect of interest is the way they moved. As mention earlier by-passing national power nodes is something ENGOs often do, however, this case illustrates the degree to which such "boomeranging" might depend on a combination of resources ENGOs can mobilise. In our case it was the social and cognitive resources specifically.

\section{Conclusions}

The Volovje reber case shows how institutional changes that followed Slovenian EU accession offered a window through which ENGOs could influence decision-making processes both within the domestic and the international context. Changes in the legal framework offered new opportunities for access to environmental justice, with some ENGOs now able to take part in formal processes (e.g. EIA), but also ENGOs now being able to direct queries to supra-national institutions in defence of the general public interest. However, to do this considerable efforts are required. This case suggests the extent to which resources along both horizontal (domestic) and vertical (international) axes had to be mobilized and organized. The combination of resources (material, cognitive, social, symbolic) needed is not easily found across ENGOs in Slovenia, but one core ENGO had enough capacity to orchestrate this task and this was possible also in a local setting with relatively unfavourable political opportunities.

In CEE policymakers are reluctant in opening up the policy arena. In this case they chose to move toward exclusion of ENGOs even when the ENGOs have been recognised rights under the newly harmonised legal framework. Yet, within a context of multi-level governance ENGOs are given the opportunity to take advantage of horizontal and vertical nodes and seek to win their battles from the outside to inside. However, it should be emphasized that this is not just a question of importing political muscles from the outside, rather a dynamic interaction between internal and external processes that evolves over time. Our analysis of the case showed how domestic and transnational processes interact in rather multi-faceted ways. While some choose to direct queries to EU institutions and seek to influence national power-nodes indirectly when these receive pressure to implement (nature protection) policy objectives from the outside (e.g. as in the case of Natura 2000 sites), others choose to reach out mostly to expertise on policy processes that they could access via membership in international well established (expert) networks and use it to develop context specific mobilisation strategies.

The Volovja reber case also well illuminates the still enormous difficulties a relatively closed political system imply despite international openings. There was a heavy load put on national courts who were asked to issue judgments from several parties and in this sense the case points at difficulties ENGOs have in performing monitoring power domestically (cf. Boström and Tamm Hallström 2010) which include low capacity and difficult access to resources needed to enable them to actively contribute to environmental policy. DOPPS, the leading ENGO benefited from membership in BirdLife International, from which it received support and through which it could interface with the EC. While the European accession has contributed to the democratisation of Slovene nature protection this study confirms earlier arguments by Börzel and Buzogány (2010), 
and other research, where they point at the challenging issues CEE countries are facing in terms of poor cooperation between state authorities and non-state actors and also a weak civil society.

In much of current policy science literature, civil society is understood as an important element for the safeguard of democratic ideals. This position is shared by the European policy maker given that during the accession period the EC sought cooperation between state and society in CEE through numerous grants, funds and programs. These sought to strengthen the position and give an active role to civil society in policy-making. Yet, this and other analyses suggests that ten years after accession there are still enormous difficulties as the ENGOs struggle to keep up with the task of holding governments accountable.

\section{References}

Baker S. 2003. The dynamics of European Union biodiversity policy: interactive, functional and institutional logics. Environmental Politics 12(3): 23-41.

Bache I, Flinders M. 2005. Multi-level governance: conclusions and implications, In Multi-level Governance, Bache I., Flinders M., (eds.). Oxford University Press: New York, pp. 195-206.

Banovec T, Mihelič J, Vidrih R., Peterlin S, Skoberne P, Wraber T. 2006. Snovalci Triglavskega narodnega parka - ljudje pred svojim časom. Bled.

Berginc M, Kremesec-Jevtenak J, Vidic J. 2007. Sistem varstva narave v Sloveniji. Ministrstvo za okolje in prostor, Ljubljana, Slovenia.

Bell, R. G. 2004. Further up the Learning Curve: NGOs from Transition to Brussels, Environmental Politics 13(1).

Bell, S., Marzano, M., Podjed, D., 2010. Inside monitoring: a comparison of bird monitoring groups in Slovenia and the United Kingdom in: Lawrence, A. (Ed.), Taking Stock of Nature: Participatory Biodiversity Assessment for Policy, Planning and Practice. Cambridge University Press, Cambridge

Bell S, Marzano M, Cent J, Kobierska M, Podjed D, Vandzinskaite D, Reinert H, Armaitiene A, Grodzin'ska-Jurczak M. 2008. What counts? Volunteers and their organisations in the recording and monitoring of biodiversity. Biodiversity Conservation 17:3443-3454.

Boh T. 2005. Implementacija habitatne direktive $v$ Sloveniji: primer vplivanja EU politik na nacionalno drzavo v procesu prilagajanja. Družboslovne razprave 21(48): 27-45.

Börzel T, Buzogány A. 2010. Environmental organisations and the Europeanisation of public policy in Central and Eastern Europe: the case of biodiversity governance. Environmental Politics 19(5): 708-735.

Boström M, Rabe L, Rodela R. 2015. Environmental non-governmental organizations and transnational collaboration: The Baltic Sea and Adriatic-Ionian Sea regions, Environmental Politics. 
Boström M, Tamm Hallström K. 2010. NGO Power in Global Social and Environmental StandardSetting. Global Environmental Politics 10: 36-59.

Boström, M. \& Karlsson M. 2013. Responsible Procurement, complex product chains and the integration of vertical and horizontal governance, Environmental Policy and Governance 23(6): 381-394

Carmin J, Vandeveer S.D. 2004. Enlarging EU Environments: Central and Eastern Europe from Transition to Accession Environmental Politics 13(1): 3-24.

Cent J., Mertens C., Niedzialkowski K., 2013. Roles and impacts of non-governmental organizations in Natura 2000 implementation in Hungary and Poland. Environmental Conservation 40: 119-128.

Císař, O. 2010. Externally sponsored contention: The channelling of environmental movement organizations in the Czech Republic after the fall of communism. Environmental Politics 19(5): 736-55.

Diani M, Rambaldo E. 2007. Still the time of environmental movements? A local perspective. Environmental Politics. 16: 765-784.

Evans, D., Demeter A, Gajdoš P, Halada L. 2013. Adapting environmental conservation legislation for an enlarged European Union: experience from the Habitats Directive. Environmental Conservation 40: 97-107.

Fairbrass J, Jordan A. 2001. Protecting biodiversity in the European Union: national barriers and European opportunities? Journal of European Public Policy 8: 499-518.

Fairbrass J, Jordan A. 2004. Multy-level Governance and Environmental Policy, in Multi-level governance, Bache I. Flinders M. (eds). Oxford University Press: Oxford, pp 147-164.

Grodzinska-Jurczak M, Cent J. 2011, Expansion of Nature Conservation Areas: Problems with Natura 2000 Implementation in Poland? Environmental Management 47(1): 11-27.

Golub J. 1996. The politics of judicial discretion: rethinking the interaction between national courts and the European Court of Justice', West European Politics. 19: 360-85.

Hann CM, Dunn E. 1996. Civil Society: Challenging Western Models. Routledge: London.

Hicks, B. 2004. Setting Agendas and Shaping Activism: EU Influence on Central and Eastern European Environmental Movements. Environmental Politics, 13(1).

Hilson C. 2002. New social movements: the role of legal opportunity. Journal of European Public Policy 9: 238-258.

Hochstetler, K., 2002. After the Boomerang: Environmental Movements and Politics in the La Plata River Basin. Global Environmental Politics 4: 35-57. 
Hooghe L, Marks G. 1996. Cohesion Policy and European Integration: Building Multi-level Governance. Oxford University Press: Oxford.

Jacobsson, K. and S. Saxonberg (eds) 2013. Beyond NGO-ization. The Development of Social Movements in Central and Eastern Europe. Ashgate.

Jančar, T. 2007. Trnova pot DOPPS-a do sodelovanja v uprav-nem postopku izdajanja okoljevarstvenega soglasja za vetrno elektrarno Volovja reber. Bilten Varuha clovekovih pravic Republike Slovenije, 11, november 2007.

Jordan A, Wurzel R, Zito A, 2003. European Governance and the transfer of new environmental policy instruments in the European Union. Public Administration 8 (3): 555-574.

Josselin, D. 2007. From transnational protest to domestic political opportunities: Insights from the Debt Cancellation Campaign. Social Movement Studies, 6(1):21-38.

Keck, M., and Sikkink, K., 1998. Activist beyond Borders: Advocacy networks in international politics. London: Cornell University Press.

Kluvánková-Oravská T, Gouldson A, Paavola J, Jílková J, Slavíková L, Chobotová V, Rauschmayer F, Zikos D, Falaleeva M, Santaoja M, Kohlheb N, Balázs B, Wirth P, Hutter G, Schanze J, Banaszak I, Trifunovová S. 2010. From Government to Governance? New Governance for Water and Biodiversity in Enlarged EU. Alfa Nakladatelství: Prague.

Krott $M$, Julien B, Lammertz M, Barbier JM, Jen S, Ballestreros $M$, de Bovis C. 2000. Voicing Interests and Concerns: NATURA 2000: an ecological network in conflict with people. Forest Policy and Economics 1: 357-366.

Kos D. 2007. Načelno mnenje številka 74. Komisija za preprečevanje korupcije. [WWWdocument]. URLwww.kpk-rs.si/sl/nadzor-in-preiskave/odlocitve-in-mnenja-komisije/nacelnamnenja/ 03/2007/nacelno-mnenje-stevilka-74

Kos D, Toš N, Kurdija S, Peršolja KP. 2003. Študija družbene sprejemljivosti projekta "Vetrne elektrarne Volovja reber", Fakulteta za družbene vede, Center za prostorsko sociologijo in Center za javno mnenje, Ljubljana.

Marks G, Hooghe L. 2004. Contrasting Visions of Multi-level Governance. In: Multi-level governance, ed Bache I, Flinders M, pp. 15-31. Oxford, UK: Oxford University Press.

McAdam, D., McCarthy, J.D., and Zald, M.N. (eds.) 1996. Comparative Perspectives on Social Movements. Political opportunities, mobilizing structures, and cultural framings. Cambridge University Press, New York.

McAdam, D. and Scott, W.R., 2005. Organizations and movements. In: G.F. Davies, D. McAdam, W.R. Scott, and M.N. Zald, eds. Social movements and organization theory. Cambridge: Cambridge University Press, 4-40. 
Mertens C, 2013. Playing at multiple levels in biodiversity governance: The case of Hungarian ENGOs in Natura 2000. Society and Economy 35: 187-208.

Meyer, D.S. 2003. Political opportunity and nested institutions. Social Movement Studies: Journal of Social, Cultural and Political Protest, 2(1), 17-35.

Ogorelec B, Mastnak M. 1999. Regijski park Snežnik: izhodišča za načrt upravljanja. Ljubljana, SI: Uprava RS za varstvo narave.

Paraskevopoulos C, Getimis P. 2006. Adapting to EU multi-level governance: regional and environmental policies in cohesion and CEE countries. Aldershot: Ashgate, UK.

Petrova, T., and Tarrow, S. 2007. Transactional and participatory activism in the emerging European polity: The puzzle of Eastern Central Europe. Comparative Political Studies 40: 74-94.

Podjed, D., Muršič, R., 2008. Dialectical relations between professionals and volunteers in a biodiversity monitoring organisation. Biodiversity and Conservation 17: 3471-3483.

Piskernik A. 1965. Iz zgodovine slovenskega varstva narave. Varstvo narave 2/3: 59-74.

Rauschmayer F, Paavola J, Wittmer H. 2009. European governance of natural resources and participation in a multi-level context: An editorial. Environmental Policy and Governance 19: 141-1.

Rodela R, Udovč $A, 2008$. Participation in nature protection: does it benefit the local community? A Trigav National Park Case Study. The International Journal of Biodiversity Science and Management 4: 209-218.

Rootes C. 1999. The transformation of environmental activism: activists, organisations and policymaking, innovation. The European Journal of Social Sciences 12:153-73.

Rootes C. 2003. Environmental Protest in Western Europe. Oxford, UK: Oxford University Press. Stoll-Kleemann S. 2001. Barriers to nature conservation in Germany: a model of explaining opposition to protected areas. Journal of Experimental Psychology 21: 369-385.

Škrl-Marega M. 2007. Načrtovanje z ljudmi ne za ljudi, in Regionalni Razvoj Slovenije, Eds Nared et al. 21-27. Ljubljana: SI. ZRC- Sazu Press.

Slepcevic R. 2009. The judicial enforcement of EU law through national courts: possibilities and limits, Journal of European Public Policy 16:378-394.

Sudbery, I. 2010. The European Union as political resource: NGOs as change agents? Acta Politica 45: 136-157.

Suškevič M. 2012. Legitimacy Analysis of Multi-Level Governance of Biodiversity: Evidence from 11 Case Studies across the EU. Environmental Policy and Governance 22(4):217-237.

Tickle A, Clarke R. 2000. Nature and landscape conservation in transition in central and southeastern Europe. European Environment 5:211-19. 
Waller, M. 2010. The environmental issue in the East of Europe: top-down, bottom-up and outside-in. Environmental Politics 19(5), 831-849.

Verbajs M. 2006. NGOs After 15 Years of Independence and a New Regime: active, but still weak. Ljubljana: Pravno-informacijski center nevladnih organizacij.Uradni List, Ljubljana.

Weber N, Christophersen T. 2002. The influence of non-governmental organisations on the creation of Natura 2000 during the European policy process. Forest Policy and Economics 4: 1-12. 